\title{
Perbaikan teknik budidaya jamur sebagai upaya dalam meningkatkan hasil produksi
}

\author{
Gustina Indriati*, Yosmet Hidayat, \& Yasrial Chandra \\ STKIP PGRI Sumatera Barat
}

*gustina_indriati@yahoo.com

\begin{abstract}
Abstrak. Belum maksimalnya penerapan teknik budidaya jamur oleh masyarakat telah memberikan pengaruh terhadap hasil budidaya. Penggunaan teknik yang kurang efektif dapat memperpanjang waktu pengerjaan dan tingginya kerusakan pada baglok jamur tiram, seperti yang dialami pengusaha MycoAgro. Kegiatan ini bertujuan memperbaiki teknik budidaya jamur dalam rangka meningkatkan produksi usaha jamur yang dimiliki masyarakat. Kegiatan ini dilaksanakan di Nagari Panyalaian Kecamatan X Koto Kabupaten Tanah Datar Sumatera Barat. Metode yang digunakan berupa pendampingan masyarakat melalui penyuluhan dan pelatihan mitra dalam pembenahan sarana budidaya, pemantapan teknik budidaya yang sudah dan belum dikuasai mitra. Pembuatan standar operasional alat budidaya dan prosedur keselamatan kerja serta pemberian konseling motivasi wirausaha pada mitra. Hasil kegiatan menunjukkan telah terjadi peningkatan pemahaman teknik budidaya yang dikuasai mitra. Mitra telah mampu menyelesaikan 2000 baglok jamur dengan waktu yang lebih cepat dari sebelumnya. Selama proses budidaya baglok yang mengalami kerusakan hanya $15 \%$, jumlah ini jauh lebih kecil bila dibandingkan dengan sebelumnya. Rata-rata produksi jamur tiram 30,7 kg/minggu. Mitra telah mampu memproduksi bibit sendiri, mengetahui teknik budidaya jamur konsumsi selain jamur tiram dan mampu menggunakan media tumbuh selain sekam kayu. Berdasarkan kegiatan yang telah dilakukan dapat disimpulkan telah terjadi peningkatan usaha budidaya jamur tiram yang dimiliki masyarakat.
\end{abstract}

Kata kunci: pleurotus; fungi; budidaya; PKM; pengabdian

\begin{abstract}
The not yet maximally the application of mushroom cultivation techniques by the community has been influence on the results of cultivation. The use of ineffective techniques can prolong working time and high damage to the oyster mushroom block, as experienced by MycoAgro businessman. This activity aims to improve mushroom cultivation techniques in order to increase the production of mushroom businesses owned by the community. This activity was carried out in the Panyalaian Nagari District X Koto, Tanah Datar District, West Sumatra. The method used is in the form of community assistance through counseling and training of partners in improving cultivation facilities, strengthening cultivation techniques that have been and have not been mastered by partners. Making operational standards for cultivation tools and work safety procedures and providing entrepreneurial motivation counseling to partners. The results of the activity showed that there had been an increase in understanding of cultivation techniques controlled by partners. Partners have been able to complete 2000 mushroom blocks with a faster time than before. There has been a division of labor with cultivation locations and work safety procedures. During the process of cultivating baglocks which were damaged only $15 \%$, this number was far smaller than before. The average production of oyster mushrooms is $30.7 \mathrm{~kg}$ / week. Partners have produced their own seeds, know the technique of consuming mushroom cultivation besides oyster mushrooms and are able to use growing media other than wood husks. Based on the activities carried out it can be concluded that there has been an increase in the cultivation of oyster mushrooms owned by the community.
\end{abstract}

Keywords: pleurotus; fungi; cultivation; PKM; devotion

To cite this article: Indriati, G., Y. Hidayat, \& Y. Chandra. 2019. Perbaikan teknik budidaya jamur sebagai upaya dalam meningkatkan hasil produksi. Unri Conference Series: Community Engagement 1: 614-622 https://doi.org/10.31258/unricsce.1.614-622

\section{(C) 2019 Authors}

Peer-review under responsibility of the organizing committee of Seminar Nasional Pemberdayaan Masyarakat 2019 


\section{PENDAHULUAN}

Jamur tiram putih merupakan bahan pangan alternatif yang disukai oleh semua lapisan masyarakat. Selain rasanya yang enak dan disukai masyarakat jamur juga memiliki kandungan yang bermanfaat bagi tubuh. Menurut Simatupang et al, (2013) jamur dipercaya berkhasiat menyehatkan maupun menyembuhkan penyakit karena mengandung protein nabati dan tidak mengandung lemak. Djarijah (2001) juga menyatakan jamur tiram mengandung 18 macam asam amino yang dibutuhkan oleh tubuh manusia. Jamur tiram juga mengadung Kalsium, Besi, Fosfor, dan Vitamin B1 (Hayuningsih, 2009). Semakin meningkatnya pemahaman masyarakat tentang kandungan gizi jamur tiram putih, maka semakin tinggi pula kebutuhan masyarakat terhadap bahan makanan bergizi tersebut. Salah satu usaha untuk memenuhi kebutuhan makanan bergizi tersebut adalah dengan meningkatkan usaha budidaya jamur tiram putih yang dimiliki masyarakat.

Program kemitraan masyarakat ini ditujukan tim pengusul terhadap pengusaha jamur tiram MycoAgro yang terdapat di Nagari Panyalaian Kecamatan X Koto Kabupaten Tanah Datar Sumatera Barat. Besarnya permintaan pasar akan jamur tiram di daerah ini telah memberikan kesempatan besar untuk berdirinya usaha ini. Daerah Panyalaian memiliki akses yang bagus dan terletak berdekatan dengan beberapa pasar tradisional, pasar kuliner dan daerah wisata seperti Pasar Koto Baru, Pasar Pandai Sikek, Pasar Padang Panjang, Pasar Padang Luar dan Kota Bukittinggi. Kondisi ini memberikan peluang besar dalam pemasaran jamur hasil panen. Namun beberapa tahun terakhir usaha ini terus mengalami kemunduran karena terhambatnya proses produksi yang disebabkan oleh banyaknya permasalahan yang dihadapi.

Pada saat ini industri rumah tangga MycoAgro mampu memproduksi baglog dalam jumlah yang tergolong rendah, bila dibandingkan lamanya waktu yang digunakan untuk proses pengolahan bahan. Hal ini disebabkan proses pengolahan yang tidak praktis sehingga memakan waktu yang lama. Pelaku usaha juga terkendala dengan besarnya biaya pembelian bibit jamur, sehingga jumlah baglog yang bisa ditanami bibit jamur menjadi terbatas. Padahal bibit jamur bisa diproduksi sendiri, namun karena teknik ini belum dikuasai sehing ga bibit masih dibeli. Produksi tubuh buah jamur juga masih rendah karena banyak baglog mengalami gagal panen akibat kontaminasi hama. Ini disebabkan perawatan yang kurang baik dan lokasi inkubasi yang belum sesuai standar. Untuk sekali produksi usaha MycoArgro hanya memperoleh laba kecil untuk satu tahapan proses produksi. Pelaku usaha perlu mengembangkan teknik dalam melakukan proses perawatan baglog jamur sehingga jumlah yang terkontaminasi atau rusak dapat ditekan dan jumlah produksi jamur bisa meningkat.

Kondisi ini juga membuat pelaku usaha menjadi putus asa, apalagi adanya tekanan negatif dari warga sekitar lokasi usaha yang memandang rendah usaha yang dijalani memperburuk kondisi mental mitra. Lazarus dan Folkman (1984) dalam Amiruddin dan Ambarini (2014) menyatakan bahwa stres merupakan konsekuensi dari proses penilaian individu, yakni pengukuran apakah sumberdaya yang dimiliki cukup untuk mengahadapi tuntutan dari lingkungan. Bila keadaan ini dibiarkan tentu akan berdampak negatif bagi pelaku usaha.

Berdasarkan analisis yang telah dilakukan tim pengusul akan melakukan kegiatan pengabdian dengan tujuan untuk pemberian motivasi dan pengembangan budidaya jamur sehingga dapat memperbaiki dan meningkatkan hasil produksi.

\section{Masalah}

Rendahnya hasil produksi jamur tiram mitra menyebabkan tidak terpenuhinya permintaan pasar. Hal ini disebabkan masih terbatasnya pengetahuan pelaku usaha terhadap teknik budidaya jamur yang baik dan efektif. Pada saat ini industri rumah tangga MycoAgro masih memproduksi baglog dalam jumlah yang tergolong rendah bila dibandingkan dengan waktu yang digunakan untuk proses pengolahan bahan. Hal ini disebabkan proses pengolahan yang tidak praktis sehingga memakan waktu yang lama. Produksi tubuh buah jamur juga masih rendah karena banyak baglog mengalami gagal panen akibat baglog mengalami kerusakan karena perawatan yang kurang baik. Usaha MycoArgro hanya memperoleh laba kecil untuk tiap tahapan produksi. Selain itu pelaku usaha juga terkendala dengan besarnya biaya pembelian bibit jamur sehingga jumlah baglog yang bisa ditanami bibit jamur menjadi terbatas. Padahal bibit jamur bisa diproduksi sendiri, namun karena teknik ini belum dikuasai sehingga bibit masih dibeli. Untuk mengatasi hal tersebut perlu dilakukan pengembangan teknik budidaya jamur yang dimiliki mitra sehingga jumlah baglok yang terkontaminasi atau rusak dapat ditekan dan jumlah produksi jamur bisa meningkat. 


\section{METODE}

Pengabdian masyarakat ini melibatkan pengusaha jamur MycoAgro Nagari Panyalaian Kecamatan X Koto Kabupaten Tanah Datar Sumatera Barat. Mengacu pada masalah yang dihadapi mitra diatas maka metode pendekatan yang dijalankan pada program ini, yaitu:

\section{Kegiatan penyuluhan}

Kegiatan pelatihan dilaksanakan pada semua anggota mitra secara lansung di lokasi budidaya. Selain itu dilakukan juga penayangan materi menggunakan infokus sehingga materi dapat diterima oleh mitra dengan lebih jelas. Penyuluhan yang diberikan berupa perbaikan teknik budidaya yang dimiliki mitra, Teknik budidaya yang belum dikuasai mitra.

\section{Pembenahan sarana dan prasarana yang dimiliki mitra}

Pembenahan sarana budidaya berupa perbaikan alat sterilisasi, pembenahan dan pembagian ruang kerja, pembuatan laminar sederhana, pembuatan rak inkubasi baglog pascapanen

\section{Pelaksanaan budidaya jamur tiram}

Media tanam dibuat menggunakan serbuk gergaji dengan komposisi serbuk gergaji 88\%, bekatul 5\% dan kapur $2 \%$ kemudian dicampur sampai rata dan ditambahkan air bersih dengan kelembaban $40 \%$. Berat media tanam baglog jamur tiram yang digunakan yaitu $1 \mathrm{~kg}$. Jadi $88 \%$ x $1000 \mathrm{gr}=880 \mathrm{gr}$, bekatul $10 \%$ x $1000 \mathrm{gr}=100 \mathrm{gr}$, dan kapur $2 \%$ x $1000 \mathrm{gr}=20 \mathrm{gr}$. Untuk pembuatan 2000 baglok maka jumlah bahan yang dibutuhkan adalah sekam kayu 60 karung, bekatul $40 \mathrm{~kg}$ dan kapur dolomit $40 \mathrm{~kg}$. Sterilisasi dilakukan dengan memanfaatkan uap panas bertekanan. Bibit jamur di inokulasikan sebanyak 5 sampai 8 biji kedalam baglog dengan cara yang aseptis diruang penanaman. Inkubasi baglog untuk pertumbuhan miselium dilakukan pada ruang inkubasi khusus yang dijaga kebersihannya. Setelah seluruh bagian baglok ditumbuhi miselium jamur, baglog dipindahkan pada rak. Mulut baglok yang ditutup kertas dibuka untuk tempat tumbuh tubuh buah jamur. Pada proses ini dilakukan penyemprotan baglog dengan air menggunakan mesin pompa otomatis yang sudah diatur waktunya untuk memberi kelembaban ruang inkubasi.

\section{Pelatihan teknik budidaya yang belum dikuasai mitra}

a. Pembuatan bibit jamur tiram

Kultur murni diperoleh dari jaringan miselium jamur yang terdapat pada daging tubuh buah jamur. Miselium diinokulasikan pada media PDA yang telah disiapkan dalam cawan petri. Media untuk pertumbuhan bibit menggunakan biji jagung yang direbus hingga empuk kemudian di pak dalam botol atau plastik dan ditutup dengan kertas. Untuk kemasan plastik pada bagian mulut diberi cicin paralon. Media yang telah siap kemudian disterilisasi.

b. Pelatihan Budidaya Jamur Konsumsi lainnya

Pada kegiatan ini diberikan juga pelatihan terhadap budidaya jamur tiram ungu dan coklat, jamur shiitake dan jamur kuping. Proses budidaya hampir sama dengan jamur tiram putih tapi bibit jamur yang diinokulasikan saja yang berbeda.

c. Pembuatan media budidaya dari bahan selain sekam kayu

Media tumbuh lain yang digunakan pada kegiatan ini adalah tongkol jagung dan ampas tebu. Kedua bahan ini dihancurkan menggunakan coper sehingga berbentuk seperti serbuk. Pada tahapan berikutnya dilakukan proses yang sama dengan budidaya jamur tiram putih.

\section{Pemberian konseling motivasi wirausaha pada mitra}

Dalam kegiatan pengabdian masyarakat ini, bimbingan konseling mengambil peran dalam upaya meningkatkan motivasi berwirausaha dalam diri mitra pengabdian. Langkah awal dilakukan studi kebutuhan layanan kepada klien dengan menggunakan metode wawancara kepada mitra. Konseling motivasi usaha diberikan untuk membangkitkan kembali percaya diri pelaku usaha untuk kembali menggiatkan usaha yang telah ditekuni.

\section{Evaluasi program}

Monitoring dan evaluasi terhadap hasil pengabdian akan dilakukan terus menerus dan berkesinambungan selama satu tahun. Setiap bulan tim pelaksana akan mengunjungi mitra petani jamur untuk melihat 
perkembangan usaha serta berdiskusi jika terdapat kendala yang dihadapi. Analisis permasalahan dilakukan untuk memastikan bahwa pengetahuan dan keterampilan yang diberikan pada kegiatan pengabdian sudah dikuasai dan dapat digunakan oleh mitra.

\section{HASIL DAN KETERCAPAIAN SASARAN}

\section{Kegiatan penyuluhan}

Sosialisasi program dilakukan secara terhadap mitra melalui presentasi power point dan arahan lansung dilokasi budidaya. Pada kegiatan ini tim lebih banyak melakukan diskusi dengan mitra membahas permasalahan yang dihadapi mitra dalam menjalankan usaha. Selama kegiatan mitra sangat antusias dalam mengikuti sosialisasi tersebut. Mitra merasa puas karena mendapatkan solusi dari permasalahan yang selama ini menjadi kendala dalam budidaya.

\section{Pembenahan sarana dan prasarana yang dimiliki mitra}

Pembenahan sarana prasarana budidaya dilakukan oleh tim bersama mitra. Kegiatan ini dimulai dari pembenahan lokasi tempat dilakukannya kegiatan budidaya yang terdiri dari pembersihan lokasi pembuatan media tanam (baglog), pembagian lokasi inokulasi bibit, lokasi baglog pasca panen dan lokasi kubung jamur. Pembenahan juga dilakukan pada peralatan sterilisasi, pembuatan inkes untuk pembuatan bibit dan pembuatan rak baglog pada kubung. Pembenahan ini sangat diperlukan untuk menekan baglog yang rusak. Menurut Widiwurjani dan Gurniarti (2016) sumber kontaminasi dalam budidaya jamur dapat berasal dari lingkungan (faktor eksternal) meliputi kebersihan lingkungan; kebersihan ruangan pembuatan bibit; termasuk ruang inokulasi atau tempat inokulasi; dan sterilisasi semua peralatan yang digunakan untuk pembuatan bibit, kebersihan pekerja dan ketepatan teknik kerja aseptis.
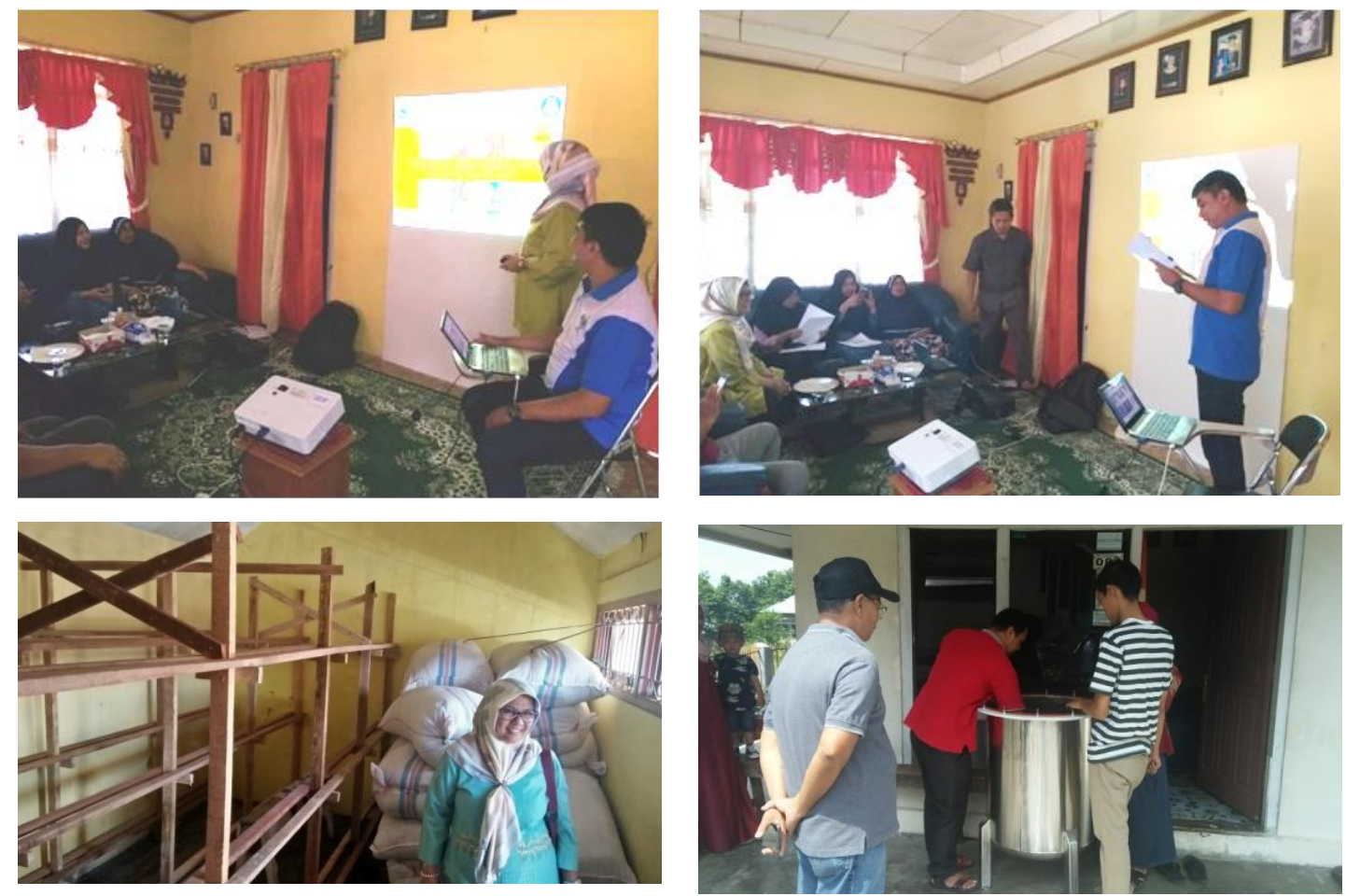

Gambar 1. Kegiatan penyuluhan dan pembenahan sarana budidaya jamur tiram

\section{Pelaksanaan pelatihan budidaya jamur}

Selama pelatihan tim pengabdian mendampingi mitra secara lansung dalam melakukan setiap proses budidaya. Hal ini bertujuan untuk mempercepat dan memudahkan mitra dalam memahami setiap tahapan kerja yang diberikan. 

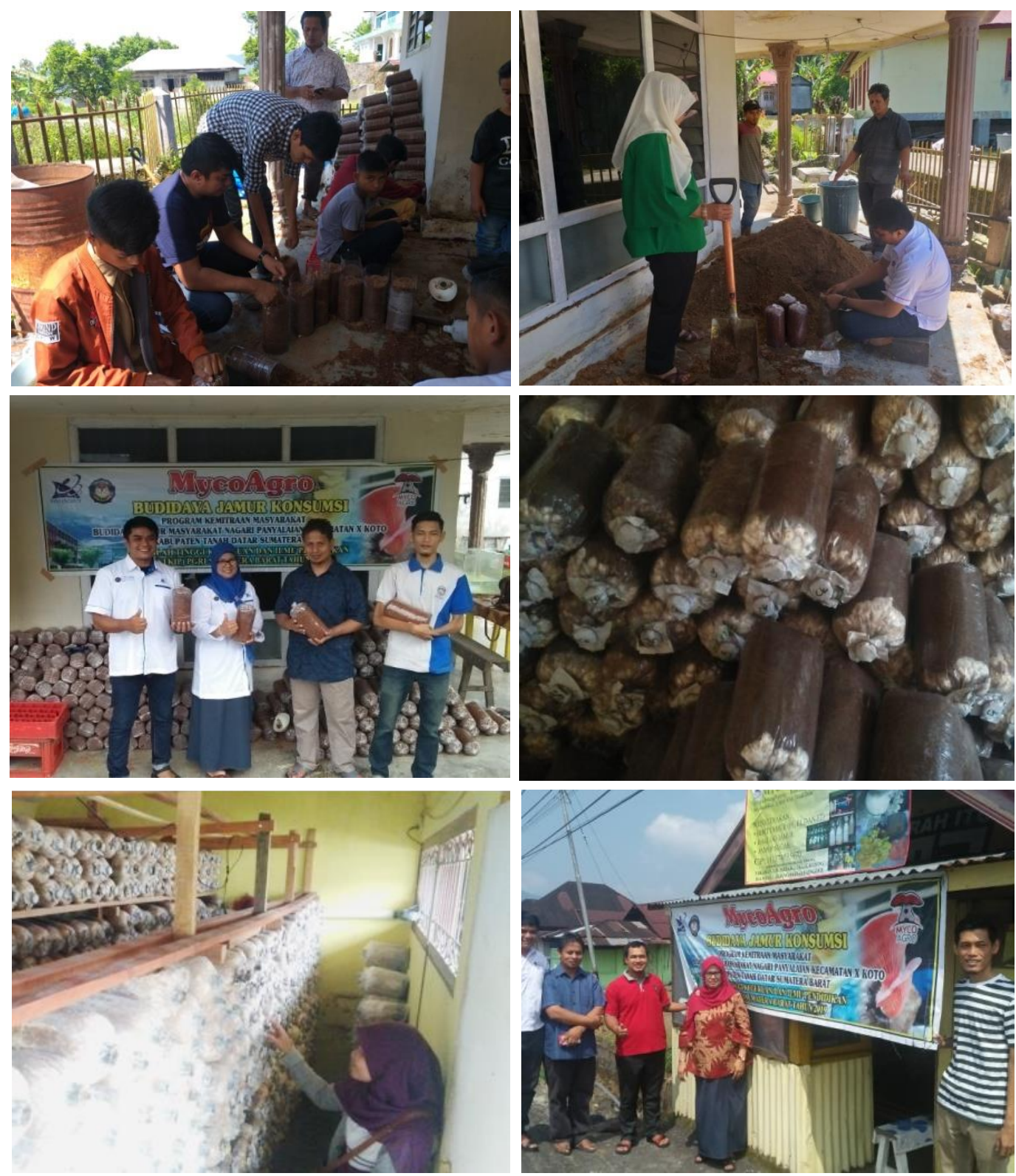

Gambar 2. Kegaitan pendampingan mitra dalam budidaya jamur tiram

Hasil kegiatan pengabdian masyarakat yang tim laksanakan bersama mitra, telah menunjukkan peningkatan produktifitas pada mitra. Secara kuantitatif dapat dilihat pada Gambar 3. dibawah ini. 


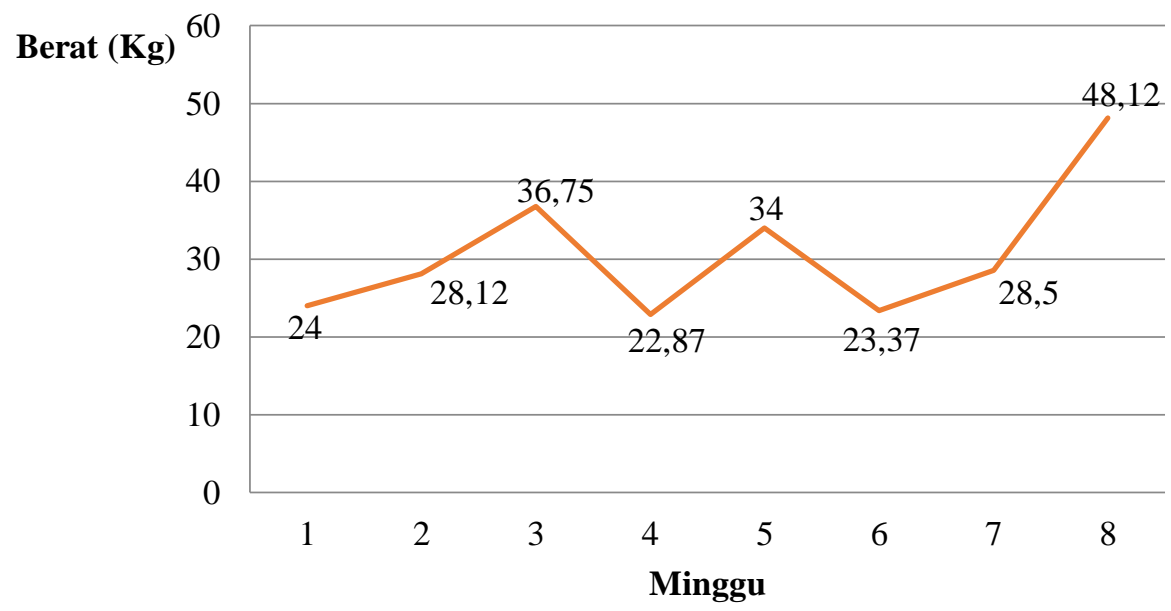

Gambar 3. Total panen per-minggu jamur tiram untuk 1000 baglog.

Pada tahap I proses budidaya telah berhasil di inkubasi sebanyak 1000 baglog yang di kubung jamur. Selama inkubasi terdapat $8 \%$ baglog yang mengalami kerusakan, lebih rendah bila dibandingkan dengan kerusakan hasil budidaya yang biasa dilakukan mitra. Jumlah produksi jamur tiram putih berbeda untuk tiap minggunya. Rata-rata 30,71 Kg/minggu jamur tiram segar diproduksi oleh mitra. Hasil ini jauh lebih tinggi bila dibandingkan dengan hasil budidaya jamur mitra sebelumnya. Menurut Achmad, dkk (2011) hasil panen yang baik jika setiap baglog menghasilkan 400-500 gram dan panen dapat berlangsung selama 4 bulan.

Tingginya produksi jamur tiram yang diperoleh pada program ini disebabkan mitra telah melakukan prosedur budidaya jamur tiram dengan baik. Ini dibuktikan dengan rendahnya jumlah baglog yang rusak atau gagal panen. Selain itu waktu yang dibutuhkan dalam proses produksi juga lebih cepat sehingga mitra bisa melanjutkan proses budidaya untuk tahapan berikutnya.

Saat ini jumlah baglog jamur yang telah berhasil diinkubasi mitra dalam waktu 2 bulan telah mencapai 2000 baglog, dimana 1000 baglog sudah dalam masa produksi dan 1000 lagi masih dalam proses penumbuhan tubuh buah jamur. Hal ini menunjukkan mitra telah mengalami percepatan waktu 1 bulan bila dibadingkan dengan sebelumnya.

Tabel 1. Perbandingan waktu yang dibutuhkan mitra dalam proses budidaya jamur tiram

\begin{tabular}{clcc}
\hline No & \multicolumn{1}{c}{ Jenis Kegiatan } & Sebelum & Sesudah \\
\hline 1 & Jumlah baglog yang di produksi & 800 baglok & 2000 baglok \\
2 & Waktu yang dibutuhkan & 2 bulan & 2 bulan \\
3 & Jumlah baglog yang rusak & $30 \%$ & $10 \%$ \\
\hline
\end{tabular}

Selain kemapuan dalam melakukan budidaya jamur tiram yang baik mitra juga telah memiliki kemampuan dalam pembuatan bibit jamur tiram. Saat ini mitra tak perlu lagi membeli bibit jamur tiram dalam menjalankan usahanya. Dengan adanya kemampuan ini mitra telah melakukan penghematan biaya pembelian bibit. 

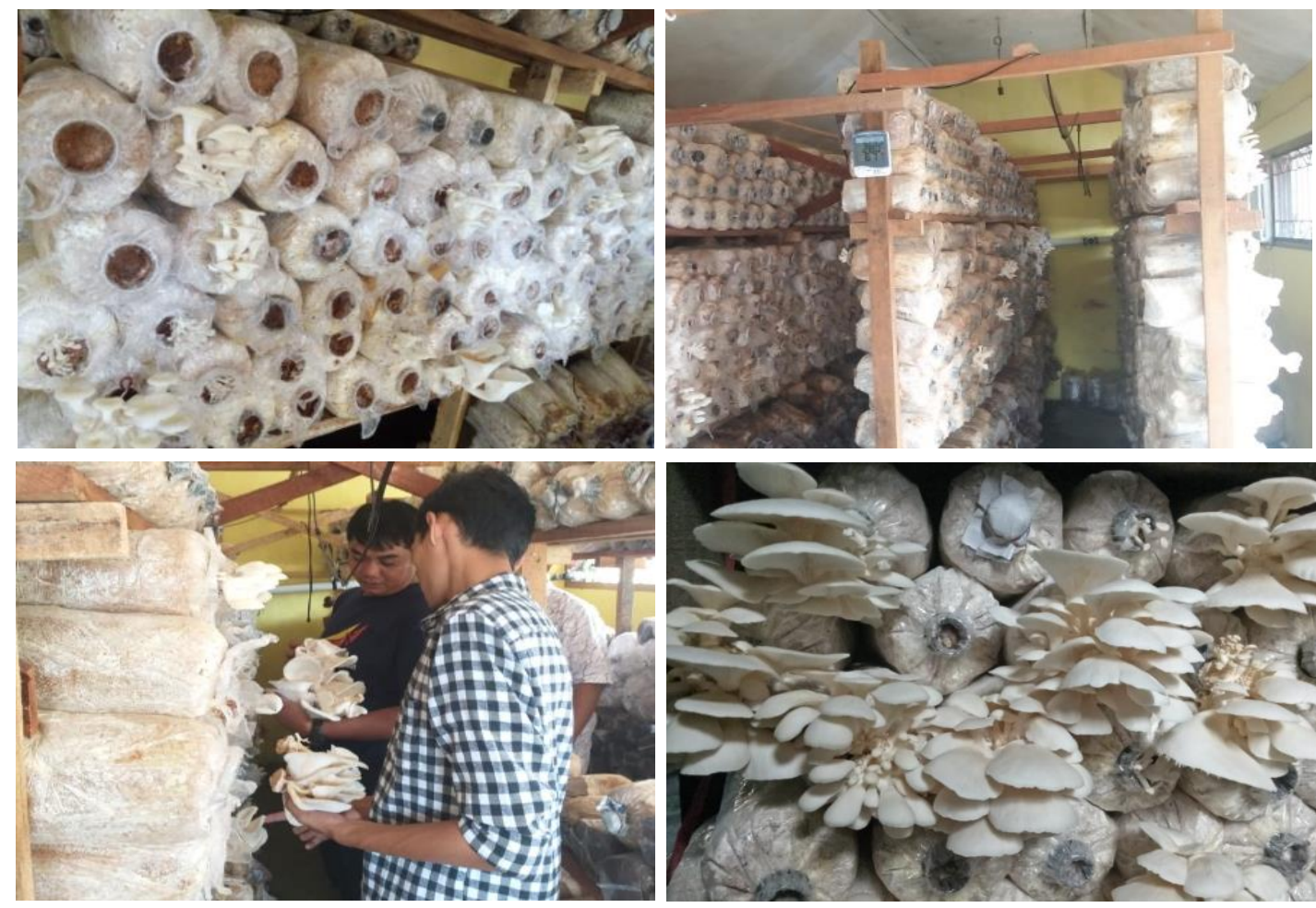

Gambar 4. Produksi jamur tiram

Teknik yang menunjang pengembangan kemampuan budidaya mitra juga telah dibekali dengan teknik budidaya berbagai jenis jamur konsumsi lainya seperti jamur kuping, jamur xitake dan jamur merang. Selain itu mitra juga telah mampu menerapkan budidaya jamur pada media skem tebu dan jerami. Adanya pengembangan ini tentu dapat memperluas kemampuan mitra dan menjadi bekal untuk mengembangkan usaha budidaya jamur yang dimiliki. Berdasarkan hasil monitoring dan evaluasi yang dilakukan diketahui bahwa mitra telah mengalami kemajuan dan peningkatan pengetahuan terkait budidaya jamur tiram yang diiringi dengan terjadinya peningkatan hasil budidaya pada berbagai aspek seperti yang telah diuraikan diatas.
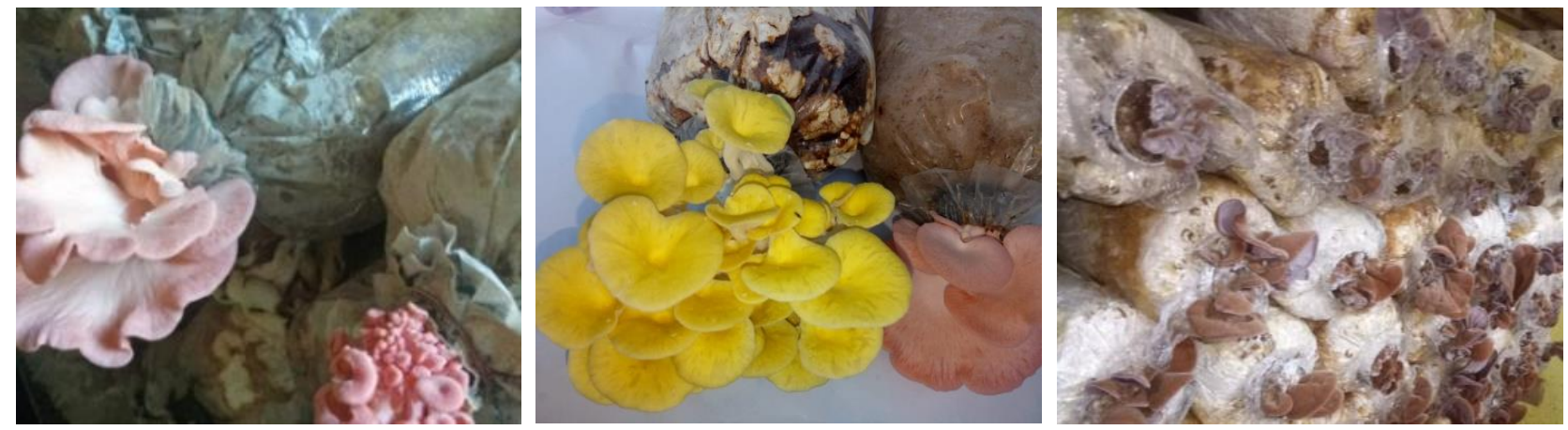

Gambar 5. Jamur hasil budidaya mitra selain jamur tiram putih

\section{Pemberian konseling motivasi wirausaha pada mitra}

Dari hasil wawancara terungkap bahwa mitra memiliki motivasi yang rendah dalam berwirausaha serta klien juga kurang memiliki aspirasi atau cita-cita yang rendah terhadap usaha yang telah dirintisnya, sehingga mengakibatkan usaha klien tidak berkembang dengan baik. Upaya yang dilakukan dalam membantu meningkatkan motivasi berwirausaha klien dalam kegiatan pengabdian ini yaitu dengan membantu menumbuhkan sikap dan perilaku yang mempengaruhi jiwa wirausaha klien melalui pelaksanaan layanan konseling. Sifat dan watak yang baik, berorientasi pada kemajuan dan positif merupakan sifat dan watak yang dibutuhkan oleh seorang wirausahawan agar wirausahawan tersebut dapat maju/sukses. Untuk itu motivasi 
(sikap dan perilaku) semangat kewirausahaan perlu dipupuk. Pengenalan motif kewirausahaan mungkin dapat menjadi salah satu titik awal untuk membangkitkan semangat kewirausahaan.
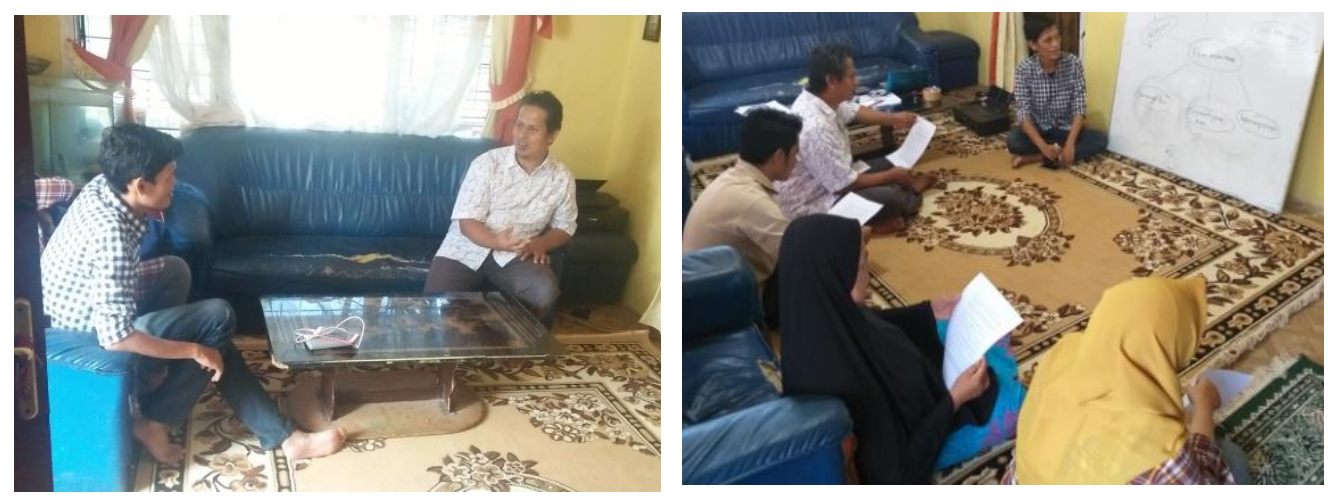

Gambar 6. Konseling motivasi wirausaha

Pelaksanaan kegiatan pengabdian masyarakat ini dilaksanakan beberapa jenis layanan dalam upaya meningkatkan motivasi wirausaha klien yaitu dengan metode layanan informasi dengan format kelompok dan layanan konseling individual. Adapun motif yang dikembangkan yaitu :

1. Motif berprestasi (the need for achievement): mendorong individu berprestasi dengan patokan prestasi dirinya sendiri atau orang lain. Satu motif untuk berwirausaha yang penting.

2. Motif berafiliasi (the need for affiliation): mendorong individu untuk berinteraksi dengan orang lain yang mengandung kepercayaan, afeksi dan empati. Motif berkuasa (the need for power): mendorong individu untuk menguasai dan memanipulasi orang lain (Kartono, 2004). Hasil dari pelaksanaan layanan dalam upaya meningkatkan motovasi berwirausaha klien/mitra telah menunjukan adanya peningkatkan pemahaman mitra tentang pentingnya motivasi dalam berwirausaha. Mitra menjadi lebih semangat dalam mengembangkan usaha jamur yang telah dirintisnya dan sudah membangun interaksi yang lebih baik dengan pelanggan-pelanggannya, sehingga sudah mulai terbangun hubungan yang lebih positif dengan rekan bisnisnya. Mitra juga telah diberikan layanan informasi tentang membangun komunikasi yang positif dengan orang lain, dan hal ini sudah mulai diaplikasikan dalam upaya menawarkan hasil budidaya jamurnya kepada rekan bisnisnya dan berdampak pada penjualan usaha yang meningkat dari sebelumnya.

\section{KESIMPULAN}

Berdasarkan program yang sudah dijalankan dapat disimpulkan bahwa transfer pengetahuan dan keterampilan kepada mitra melalui program ini telah tercapai. Hal ini terlihat dengan telah adanya kemampuan mitra menerapkan dan memanfaatkan keterampilan tersebut yang diiringi dengan peningkatan proses budidaya jamur pada berbagai aspek.

\section{UCAPAN TERIMA KASIH}

Terima kasih kami sampaikan kepada Menristekdikti yang telah memberikan dana dan telah berkontribusi dalam kegiatan.

\section{DAFTAR PUSTAKA}

Achmad., Mugyono, T. Arlianti, \& C. Azmi. 2011. Panduan Lengkap Jamur. Jakarta: Penebar Swadaya.

Amiruddin, J. H., \& T. K. Ambarini. 2014. Pengaruh Hardiness dan Coping Stress Terhadap Tingkat Stres pada Kadet Akademi TNI-AL. Jurnal Psikologi Industri dan Organisasi, 3(2).

Djarijah, N. M., \& A.S. Djariyah. 2001. Budi Daya Jamur Tiram. Penerbit Kanisius. Yogyakarta.

Hayuningsih, D. R. W., S. Dwi, \& P. Kurnia. 2009. Perbedaan kandungan protein, zat besi dan daya terima pada pembuatan bakso dengan perbandingan Jamur tiram (Pleurotus sp) dan daging sapi yang berbeda. Skripsi Fakultas Ilmu Kesehatan Universitas Muhammadiyah. Surakarta. 
Simatupang, E., Murniati, \& Saputra, S.I. 2013. Pengaruh Pemberian Beberapa Dosis Bekatul pada pedium Serbuk Gergaji terhadap Pertumbuhan dan Produksi Jamur Tiram Putih (Pleurotus ostreatus). Jurusan Agroteknologi Fakultas Pertanian. Universitasas Riau. Riau

Widiwurjani., \& Guniarti. 2016. Potensi Bibit Jamur Tiram Hasil Biakan dari Agroindustri. Jatim; UPN Veteran 